\title{
The Qualitative and Quantitative Phytochemical Investigation of Crinum Species in Ethiopia
}

\author{
Asnakech Senbeta ${ }^{1,}$, Tesfaye Awas $^{2}$, Abdella Gure ${ }^{3}$ \\ ${ }^{1}$ Crop \& Horticulture Biodiversity Directorate, Ethiopian Biodiversity Institute, Addis Ababa, Ethiopia \\ ${ }^{2}$ Forest \& Range Land Plants Biodiversity Directorate, Ethiopian Biodiversity Institute, Addis Ababa, Ethiopia \\ ${ }^{3}$ Department of Forestry, Wondo Genet College of Forestry \& Natural Resources, Hawassa Universities, Wondo Genet, Ethiopia
}

Email address:

asni.senbeta@gmail.com (A. Senbeta), tesfayeawas@gmail.com (T. Awas), abdellag66@gmail.com (A. Gure)

${ }^{*}$ Corresponding author

\section{To cite this article:}

Asnakech Senbeta, Tesfaye Awas, Abdella Gure. The Qualitative and Quantitative Phytochemical Investigation of Crinum Species in Ethiopia. International Journal of Photochemistry and Photobiology. Vol. 3, No. 1, 2019, pp. 1-9. doi: 10.11648/j.ijpp.20190301.11

Received: May 13, 2019; Accepted: June 13, 2019; Published: July 2, 2019

\begin{abstract}
Medicinal plants have a long history of use in most communities all over the world. Plants have the ability to synthesize a wide diversity of chemical compounds that uses to perform important biological functions. Many of Genus Crinum has been broadly used in traditional and ethno-medicines in the world wide. The aims of this study were to investigate the qualitative and quantitative phytochemicals constituents of the four species of the genus Crinum that exists in Ethiopia. All experiments were follow standard procedures. For the purpose of conducting phytochemical analyses on the four species each, three to six bulbs were collected from Field Gene Banks, Botanical Gardens and local fields. The bulb samples were cleaned, dried and crushed into powder. In this study the cold extraction methods were used the extraction solvents such as: n-hexane, ethanol, methanol and water. As a result of the phytochemical analyses, it revealed the presence of alkaloids, flavonoids, saponins, tannins and phenols in Crinum abyssinicum and Crinum bambusetum species. Likewise, it confirmed the presence of alkaloids, flavonoids, phenols and tannins in Crinum macowanii. Moreover, it confirmed the presence of alkaloids, flavonoids, phenols and tannins Crinum ornatum. The chemical constituents revealed the presence of relatively high concentration of alkaloids $(9.66 \%)$, saponins $(19.72 \%)$, phenols $(10.33 \%)$, and tannins $(0.61 \%)$ in the bulbs of Crinum bambusetum. Similarly, the highest concentration of flavonoids (27.72\%) was recorded from the bulbs of Crinum ornatum. As more phytochemicals constituents are being identified and tested, traditional uses of the Crinum are being verified. Accordingly, the evidence on the chemical constituents of the species explains the uses of the plants. Therefore, it is worthwhile to recommend the use of the phytochemical constituents of the species studied for Pharmaceutical use in the treatment of different diseases.
\end{abstract}

Keywords: Crinum Abyssinicum, Crinum Bambusetum, Crinum Macowanii, Crinum Ornatum, Bulbs, Phytochemical Screening, Qualitative, Quantitative

\section{Introduction}

Medicinal plants have a long history of use in most communities throughout the world. Nature has been a source of medicinal agents for thousands of years. Plants which have one or more of its organs containing substances that can be used for the healing purpose, are called medicinal plants [1]. Genus Crinum is one of the medicinal plants that belong to the family Amaryllidaceae, It comprises of an 'eye-catching group' of tropical and sub-tropical lilies distributed in almost every part of the world, mainly in Africa, Asia, Australia and
America. Globally, around 180 Crinum species were described [2-4]. Out of these, four species are found in Ethiopia: namely, Crinum abyssinicum, Crinum bambusetum, Crinum macowanii and Crinum ornatum [5]. Crinum abyssinicum and Crinum bambusetum are endemic species of Ethiopia [5].

Generally, bulbs of Crinum species are used to treat several diseases, like antitumor, anti-coughs and colds, immune-stimulating, analgesic, antiviral, anti-malarial, antibacterial, antifungal activities, etc [6]. In Ethiopia, Crinum abyssinicum is used for treatment of Hypertension 
[7], animals' internal parasites [8] and Hepatitis B treatment and Skin infection [9]. In addition to this, Ethiopian traditional healers' used Crinum species for the treatment of cancer, asthma, colds, malarial, so on. Due to an endless source of bioactive principles, economic importance and medicinal purposes of Crinum, it needs especial attention for investigation of phytochemical constituents. Phytochemicals are natural compounds found in plants that are responsible for the colour, taste and aroma of foods [10]. Internationally, about 35 crinum species have been investigated for phytochemical constituents, whereas the largest number of the species yet to be studied [11]. The chemistry and economic importance of Crinum species have never been studied in-depth in Ethiopia, suggesting that due to lack of awareness about their significance, these species are not accorded the necessary intervention to save them by the rural communities. In order to promote their use at a larger scale and improve their socioeconomic contributions, phytochemical investigations are necessary to isolate diverse classes of compounds contained in their bulbs. The aim of this study was to analyze the major phytochemical constituents of the four species of the bulbs of genus Crinum that are known from Ethiopia.

\section{Materials and Methods}

\subsection{Collection and Identification of Plant Materials}

A healthy fresh bulb of Crinum species were collected from our institute medicinal plant field gene banks, botanical gardens and local fields that not from protected areas it gazer from highly disturbed grazing fields and no specific permission was required for collection. Identification of the plant was made by a botanist at Ethiopian Biodiversity Institute (Dr Tesfaye Awas) who is expert in the flora of the collection site and a voucher specimen was deposited at the Herbarium of Ethiopian Biodiversity Institute under voucher number Tesfaye Awas and Asnakech Senbeta 2644 (Crinum abyssinicum), Tesfaye Awas and Asnakech Senbeta 2645 (Crinum bambusetum), Tesfaye Awas and Asnakech Senbeta 2646 (Crinum ornatum) and Tesfaye Awas and Asnakech Senbeta 2647 (Crinum macowanii).

\subsection{Preparation of Sample and Extracts}

The bulbs were cleaned, cut into small pieces and air dried in laboratory at room temperature [12]. After drying, the materials were ground into fine powder and stored it until use. The sample extraction were done by macerated in cold solvent in 1: 4 ratios for 72 hours through proceeding from non-polar to polar solvent; i.e., n-Hexane, ethanol, methanol and water [13]. Extracts obtained were filtered, concentrated and evaporated into solid extracts under room temperature. Then the extracted materials were stored in a refrigerator at $4^{\circ} \mathrm{C}$ until they were used [14]. The laboratory experiments were conducted in Ethiopian Biodiversity Institute, Ethiopian Public Health Institute and National Soil Testing Center.

\subsection{Phytochemical Screening}

\subsubsection{Qualitative Phytochemical Analysis}

Phytochemical screening of various constituents of Crinum species were carried out by standard methods [1, 14-19] as described below

i. Alkaloids.

For each test $0.5 \mathrm{~g}$ extracts were dissolved in $5 \mathrm{ml}$ of dilute (1\%) hydrochloric acid on a steam bath and filtered with cotton in test tube.

Mayer's Test: $1 \mathrm{ml}$ of filtrates was treated with a few drops of Mayer's reagent (Potassium Mercuric Iodide). Formation of a yellow coloured precipitate indicates the presence of alkaloids.

Hager's Test: $1 \mathrm{ml}$ of filtrates was treated with a few drops of Hager's reagent (saturated picric acid solution) formation of crystalline yellow precipitate indicates the Presence of alkaloids.

Dragendroff's Test: $1 \mathrm{ml}$ of filtrates was treated with a few drops of Dragendroff's reagent (solution of Potassium Bismuth Iodide). Formation of Orange red precipitate indicates the presence of alkaloids.

ii. Flavonoids.

Alkaline reagent test: $0.1 \mathrm{~g}$ extract were mixed with $2 \mathrm{ml}$ of $2 \%$ solution of $\mathrm{NaOH}$, an intense yellow colour was formed which turned colorless on addition of few drops of diluted $\mathrm{H}_{2} \mathrm{SO}_{4}$ acid which indicated the presence of flavonoids.

Lead acetate Test: $0.1 \mathrm{~g}$ extracts dissolved with $5 \mathrm{ml}$ solvent, $2 \mathrm{ml}$ of the solutions were treated with 3-5 drops of $10 \%$ lead acetate solution. Formation of yellow or orange color precipitate indicates the presence of flavonoids.

Ammonia test: $0.1 \mathrm{~g}$ extracts were mixed with $2 \mathrm{ml}$ of $10 \%$ $\mathrm{NH}_{4} \mathrm{OH}$ solution with few drops of concentrated $\mathrm{H}_{2} \mathrm{SO}_{4}$, yellow color formed which turned colorless indicated the presence of flavonoids.

iii. Phenols.

$0.5 \mathrm{~g}$ of each extracts were dissolved by $10 \mathrm{ml}$ of each solvents than filter it with cotton.

Alkaline reagent: $1 \mathrm{ml}$ of extract was mixed with $2 \mathrm{ml}$ of $2 \%$ solution of $\mathrm{NaOH}$, an intense yellow color fade to colorless.

Lead acetate test: When $2 \mathrm{ml}$ of extract was treated with few drops of $5 \%$ lead acetate solution, white precipitates appeared.

Ferric Chloride Test: $2 \mathrm{ml}$ extracts were treated with 3-4 drops of $5 \%$ ferric chloride solution. Formation of bluish black color indicates the presence of phenols.

iv. Tannins.

The extract $0.5 \mathrm{~g}$ was boiled in $10 \mathrm{ml}$ of each solvent in a test tube for $5 \mathrm{~min}$ then the mixture was filtered by cotton and use for the tests.

Test with Iron salts: crude extract show colour reaction with iron salt like $\mathrm{FeCl}_{3}$ and $\mathrm{K} 4 \mathrm{Fe}(\mathrm{CN}) 6$ in presence of ammonia. Addition of 2-3 drops of $5 \% \mathrm{FeCl}_{3}$ solution to the solutions of tannins forms bluish black precipitate or tannins it forms greenish brown coloured precipitate.

Lead acetate test: When $2 \mathrm{ml}$ of extract was treated with 
few drops of $5 \%$ lead acetate solution, white precipitates appeared.

Ferric chloride test: To $5 \mathrm{ml}$ of extract few drops of $1 \%$ $\mathrm{FeCl}_{3}$ were added. The appearance of blackish-blue or blackish-green colour indicates the presence of tannins.

Gelatin Test: To $2 \mathrm{ml}$ extract, $1 \mathrm{ml}$ of $1 \%$ gelatin solution containing sodium chloride $(10 \% \mathrm{NaCl})$ was added white precipitate indicates the presence of tannin.

v. Saponins.

Foam Test: $0.5 \mathrm{gm}$ of extract was shaken with $2 \mathrm{ml}$ of distil water. If stable foam produced persists for 15 minutes it indicates the presence of saponins.

Sodium nitrate test: $0.1 \mathrm{~g}$ of extract was dissolved in to alcoholic or water, then $2 \mathrm{ml}$ of the solution was treated with $10 \% \mathrm{NaNO}_{3}$ and few drops concentrated $\mathrm{H}_{2} \mathrm{SO}_{4}$, blood red colors indicate the presence of saponins.

vi. Steroid

Salkowski's test: $0.1 \mathrm{~g}$ of crude extract was mixed with $2 \mathrm{ml}$ of chloroform and few drops of concentrated $\mathrm{H}_{2} \mathrm{SO}_{4}$ were added sidewise. Shake it and allowed to stand for some minute, a red color produced in the lower chloroform layer indicated the presence of steroids.

$3 \%$ Vanillin conc. $\mathrm{H}_{2} \mathrm{SO}_{4}: 0.1 \mathrm{~g}$ crude extract was mixed with $2 \mathrm{ml}$ of chloroform and 3-5 drop of 3\% Vanillin conc. $\mathrm{H}_{2} \mathrm{SO}_{4}$ were added the development of a rose or reddish brown color indicated the presence of steroids.

vii.Glycosides.

Liebermann's test: $0.1 \mathrm{~g}$ crude extract was mixed with $2 \mathrm{ml}$ of chloroform and $2 \mathrm{ml}$ of acetic acid. The mixture was cooled in ice. Carefully, a few drops of concentrated $\mathrm{H}_{2} \mathrm{SO} 4$ were added, a color change from violet to blue to green.

Salkowski's test: $0.1 \mathrm{~g}$ crude extract was mixed with $2 \mathrm{ml}$ of chloroform. Then $2 \mathrm{ml}$ of concentrated $\mathrm{H} 2 \mathrm{SO} 4$ was added carefully and shaken gently a reddish brown colour appear.

viii. Anthraquinones.

Borntrager's test: $0.1 \mathrm{~g}$ extract was dissolved by $5 \mathrm{ml}$ dil. $\mathrm{HCl}$ acid. The hydro alcoholic extract of sample was shaken vigorously with $10 \mathrm{ml}$ of benzene. The extract was then filtered and the filtrate was treated with $5 \mathrm{ml}$ of $10 \%$ of ammonia solution, the mixture was shaken and the presence of a pink, red or violet color in ammonia phase indicted the presence of free Anthraquinones glycosides.

Modified Borntrager's: 0.1g extracts were hydrolyzed with $5 \mathrm{ml}$ dil. $\mathrm{HCl}$ then treated with a few drops of $1 \%$ Ferric Chloride solution and immersed in boiling water for about 5 minutes. The mixture was cooled and extracted with equal volumes of benzene. The benzene layer was separated and treated with ammonia solution. Formation of rose-pink colour in the ammonia layer indicates the presence of Anthraquinones glycosides.

ix. Cardiac glycosides.

Liebermann Bruchard's reagent: $0.1 \mathrm{~g}$ of extract was dissolved with $3 \mathrm{ml}$ of glacial acetic acid followed by addition of a mixture of acetic anhydride and conc. $\mathrm{H}_{2} \mathrm{SO}_{4}$ (50: 1) was added from the sides of the test tube showed a rose color which turns to greenish blue indicted the presence of Cardiac glycosides.
Keller- Kiliani reaction: $0.1 \mathrm{~g}$ extract was dissolved with 3 $\mathrm{ml}$ of glacial acetic acid and $1 \mathrm{ml}$ of conc. $\mathrm{H}_{2} \mathrm{SO}_{4}$ was added carefully against the wall of test tube followed by $2-3$ drops of $1 \% \mathrm{FeCl}_{3}$ solution, formation of a bright blue color indicted the presence of Cardiac glycosides sugars.

$\mathrm{x}$. Terpenoids.

$0.1 \mathrm{~g}$ of the extract was dissolve in $2 \mathrm{ml}$ of chloroform and evaporates to dryness. $2 \mathrm{ml}$ of concentrate sulphuric acid was added and heat for about $2 \mathrm{~min}$. A grayish colour indicates the presence of terpenoids.

\subsubsection{Quantitative Determination Tests}

Quantitative analyses were carried out on the samples to determine the amount of phytochemical composition. The analyses were done based on standard procedures as described below:

i. Determination of total Alkaloid content following the Method [15].

For total alkaloids content determination $5 \mathrm{~g}$ of the extract was taken into a $250 \mathrm{ml}$ beaker and added $200 \mathrm{ml}$ of $10 \%$ acetic acid in ethanol. The mixture was covered and kept it for $4 \mathrm{hrs}$ at room temperature. Then filtered it by Whatman filter paper into a $250 \mathrm{ml}$ conical flask and concentrated it through evaporation on a water bath up to one-fourth of the original volume. On the filtrate adding it concentrated ammonium hydroxide drop wise until the total precipitation was formed, and allowed to settle it. After that the precipitates was washed by dilute ammonium hydroxide then filter, dried, cooled in desiccators and reweighed. The process was repeated three times and the average was taken. The final weight was expressed as percentage of weight of the sample analyzed as shown below [15].

$$
\% \text { of Alkaloid }=\frac{W_{2}-W_{1}}{\text { Weight of Sample }} * 100
$$

Where, W1 - is weight of filter paper, and W2 - is the weight of filter paper + alkaloid precipitate

ii. Determination of Total Saponins Content Following the Method [20].

For total saponins content determination $20 \mathrm{~g}$ of samples powder was taken into a conical flask and added it $50 \mathrm{ml}$ of $20 \%$ aqueous ethanol. The samples were heated over a hot water bath for $4 \mathrm{hrs}$ with continuous stirring at about $55^{\circ} \mathrm{C}$. The mixture was filtered and the residue re-extracted with another $100 \mathrm{ml} \mathrm{20 \%}$ ethanol. The combined extracts were reduced to $40 \mathrm{ml}$ over water bath at about $90^{\circ} \mathrm{C}$. The concentrate was transferred into a $250 \mathrm{ml}$ separating funnel and $10 \mathrm{ml}$ of diethyl ether was added and shaken vigorously. The aqueous layer was recovered while the ether layer was discarded. The purification process was repeated. $30 \mathrm{ml}$ of $\mathrm{n}$ butanol was added. The combined n-butanol extracts were washed twice with $10 \mathrm{ml}$ of $5 \%$ aqueous sodium chloride. The remaining solution was heated in a water bath. After evaporation the samples were dried in the oven to a constant weight and the saponins content was calculated as percentage of the original sample thus 


$$
\% \text { of Saponin }=\frac{\mathrm{W}_{2} \mathrm{~W}_{1}}{\text { Wheight of Sample }} * 100
$$

Where, W1- is weight of evaporating dish, and W2 - is weight of dish + sample

iii. Determination of Total Flavonoids Content Following the Method [21-22].

The total flavonoids content was determined by extracting $10 \mathrm{~g}$ of the plant sample with $100 \mathrm{ml}$ of $80 \%$ aqueous methanol at room temperature. The solutions were filtered through no. 42 filter paper into weighed crucibles. Then, the crucibles' contents were evaporated to dryness over water baths and the final weights were determined as follows.

$$
\% \text { of Flavonoid }=\frac{\mathrm{W}_{2} \mathrm{~W}_{1}}{\text { Wheight of Sample }} * 100
$$

Where, W1- is weight of empty crucible and W2- is weight of crucible + Flavonoids extract

iv. Determination of Total Phenols Content.

The total phenol content was determined by FolinCiocalteu examine method with spectrophotometry [23-25]. For examine taking $1 \mathrm{~g}$ of sample powder to extract with 10 $\mathrm{ml}$ of $80 \%$ methanol. The reaction mixture consists of $1 \mathrm{ml}$ of extract and $9 \mathrm{ml}$ of distilled water was taken in a volumetric flask $(25 \mathrm{ml}) .1 \mathrm{ml}$ of Folin-Ciocalteu phenol reagent was treated to the mixture and shaken well. After 5 minutes, 10 $\mathrm{ml}$ of $7 \% \mathrm{Na} 2 \mathrm{CO} 3$ solution was treated to the mixture. The volume was made up to $25 \mathrm{ml}$. A set of standard solutions of gallic acid $(20,40,60,80$ and $100 \mathrm{mg} / \mathrm{ml})$ were prepared in the same manner as described earlier. Protected for 90 minutes at room temperature and the absorbance for test and standard solutions were determined against the reagent blank at $550 \mathrm{~nm}$ with an UV/VIS spectrophotometer. Quantification was done on the basis of a standard curve of gallic acid. Based on the measured absorbance, the concentration of phenols was read $(\mathrm{mg} / \mathrm{ml})$ from the calibration line; then the content of phenols in extracts was expressed in terms of gallic acid equivalent (mg of GA/g of extract).

Total phenol content $=\mathrm{GAE} \times \mathrm{V} \times \mathrm{D} / \mathrm{m}$, where $\mathrm{GAE}$ is the gallic acid equivalence $(\mathrm{mg} / \mathrm{mL}) ; \mathrm{V}$ is the volume extract $(\mathrm{mL}), \mathrm{D}$ is dilution factor and $\mathrm{m}$ is the weight $(\mathrm{g})$ of the pure plant extract.

v. Determination of Total Tannins Content.

The total tannins content were determined by FolinCiocalteu method [25-26]. About $0.1 \mathrm{ml}$ of the sample extract was added to a volumetric flask $(10 \mathrm{ml})$ containing $7.5 \mathrm{ml}$ of distilled water and $0.5 \mathrm{ml}$ of Folin-Ciocalteu reagent, $1 \mathrm{ml}$ of $35 \% \mathrm{Na} 2 \mathrm{CO} 3$ solution and dilute to $10 \mathrm{ml}$ with distilled water. The mixture was shaken well and kept at room temperature for $30 \mathrm{~min}$. A set of reference standard solutions of gallic acid $(20,40,60,80$ and $100 \mathrm{mg} / \mathrm{ml})$ were prepared in the same manner as described earlier. Absorbance for test and standard solutions were measured against the blank at $725 \mathrm{~nm}$ with an UV/Visible spectrophotometer. The tannin content was expressed in terms of $\mathrm{mg}$ of GAE / $\mathrm{g}$ of extract.

\section{Statistical Analysis}

All laboratory experiments were carried out triplet for each extract $(\mathrm{n}=3)$. The statistical analyses were performed by one-way analysis of variance (ANOVA) followed by Tukey test of multiple mean comparisons at $5 \%$ level of significance and SPSS (version 20.0).

\section{Results and Discussion}

\subsection{Qualitative Phytochemical Analysis}

Phytochemical screening was carried out on crinum species to test the presence of most relevant bioactive compounds uses for medication. The presences of phytochemicals constituents in crinum were evaluated from the extracts of crinum species bulbs by successive solvent method such as n-hexane, ethanol, methanol and aqueous solvents. The strongest confirmation of the presences or absences of phytochemical constituents in the bulbs of crinum were detected with more than one reagent used for each bulbs extracts. In these tests, it reveals the presence of various bioactive secondary metabolites which might be responsible for the medicinal attributes. The investigation of chemical constituents of the plants shows that, the bulbs of genus Crinums are rich in phytochemical compositions. As it can be observed in the Table 1 alkaloids, flavonoids, phenols, saponins and tannins were detected accordingly, in the crude extracts of with some reagents in all Crinum species except n-hexane solvent. But the detection of Anthraquinones glycosides, cardiac glycosides and terpenoids for all crinum species were negative by all reagent tests in all solvent extracts. Qualitative phytochemical investigation results of crinum abyssinicum and crinum bambusetum revealed that, the presence of alkaloids, flavonoids, phenols, saponins and tannins was confirmed in all reagents with different solvent extracts except n-hexane, in the extract of crinum bambusetum the presence of steroid and glycosides detected by only one reagent. In addition to this, they detected in crinum abyssinicum in ethanol and methanol extract respectively, but they detected in crinum bambusetum in ethanol and aqueous extracts accordingly. Thus, crinum bambusetum and crinum abyssinicum results almost similar detection of phytochemicals constituents. Moreover, both species are endemic to Ethiopia and had been never investigated for the presence of phytochemicals constituents so far. Most notably, the crinum macowanii detection revealed positive test for alkaloids, flavonoids, phenols and tannins with some reagents in ethanol, methanol and aqueous extracts. Similarly, the presence of saponins and steroid were detected in this species by only one reagent in aqueous extract whereas glycosides detected in ethanol extract. The presence of alkaloids in crinum macowanii was consistent with previous findings [27-29].

The qualitative phytochemical investigation result of Crinum ornatum showed that, the presence of alkaloids, flavonoids, phenols and tannins in all solvent extracts expect n-hexane. But, in this species saponins, steroid and 
glycosides were absent by all reagent in all solvent extracts. The absence of saponins in Crinum ornatum was contradicted with the opinion of the person [30] who noted that saponins are one of the active constituents. On contrary, the absence of saponins in Crinum ornatum was consistent with the observation of previous study [31]. In addition, the absence of Anthraquinones glycosides in the species was in line with the reports of previous study [30] and the absence of cardiac glycoside was observed against the previous findings [31]. Some Crinum species that aren't found in Ethiopia are investigated for alkaloids and flavonoids constitutes and results a positive test [32] Such as: Crinum jagus, Crinum latifolium etc, which is go in line with the results of Ethiopia Crinum. According to the phytochemical screening of Crinum jagus indicated the presence of tannins, alkaloids, sterols, triterpenes, flavonoids, phenols and saponins [33]. In the same manner, phytochemical studies on Crinum defixum bulbs exposed the presence of alkaloids, Saponins, tannins, phenols and Flavonoids [34]. Many plant extracts are reported to have health beneficial properties due to secondary metabolites such as alkaloids, tannins, phenols, steroids, saponins, flavanoids, terpenoids, glycosides, anthroquinones glycosides, cardiac glycosides and so on. These bioconstituents are known for their multipurpose biological effects and are implicated in treatment of various diseases. Some of the literature reveals that, lot of pharmacological investigations have been carried on crinum species. Most notably, almost all reported that pharmacological uses the bulbs of crinum species to treat several diseases, like antitumor, anti-coughs and colds, immune-stimulating, analgesic, antiviral, anti-malarial, antibacterial, antifungal activities, etc [6].
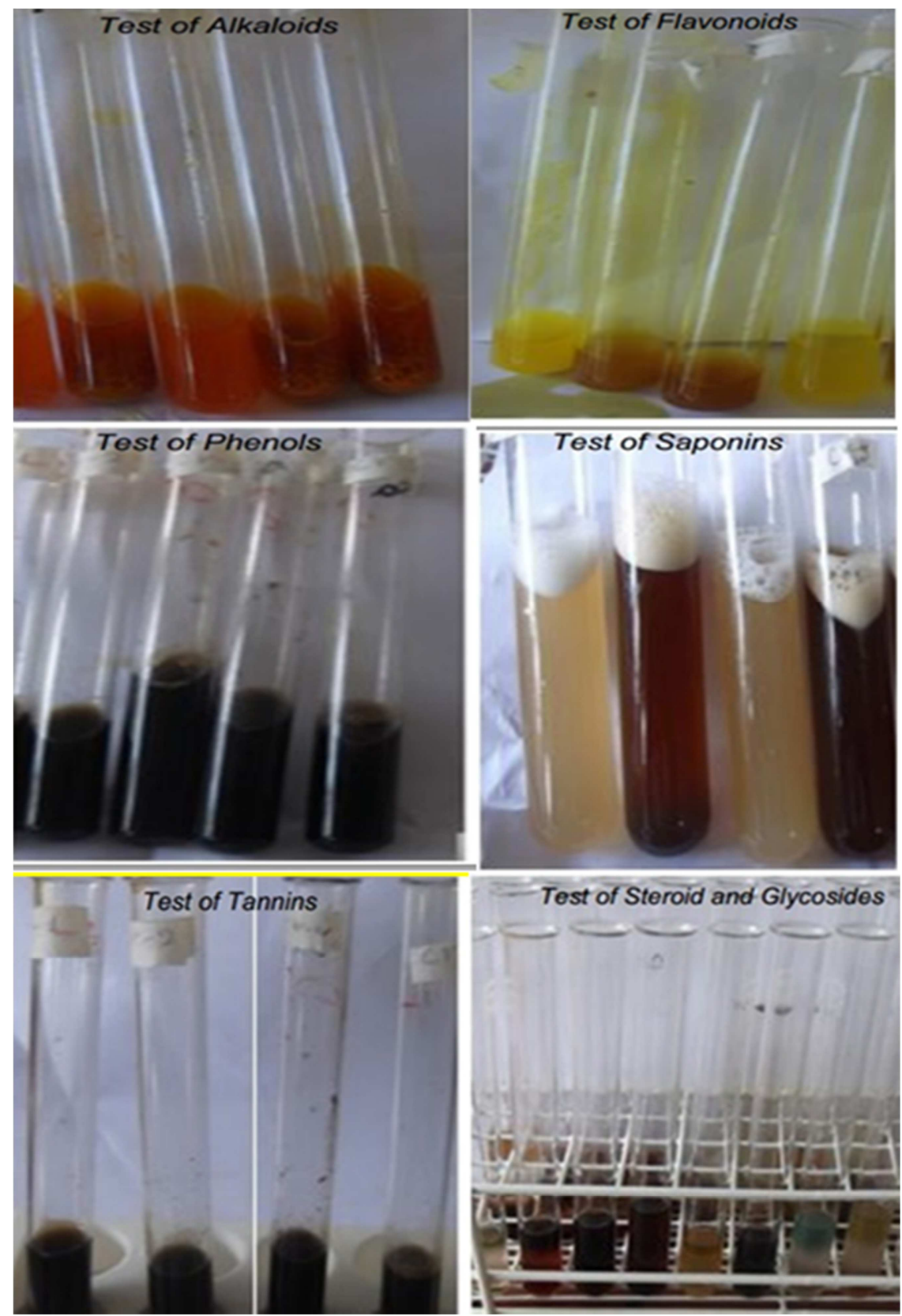

Figure 1. The positive tests results of phytochemical constituents. 
Table 1. Result of qualitative phytochemical screening of Crinum species.

\begin{tabular}{|c|c|c|c|c|c|c|c|c|c|}
\hline \multirow{3}{*}{$\begin{array}{l}\text { Phytochemical } \\
\text { test }\end{array}$} & \multirow{3}{*}{ Reagents } & \multicolumn{8}{|c|}{ Results of Different Crinum species extract by different solvent } \\
\hline & & \multicolumn{4}{|c|}{ Crinum abyssinicum } & \multicolumn{4}{|c|}{ Crinum bambusetum } \\
\hline & & n-Hexane & Ethanol & Methanol & Water & n-Hexane & Ethanol & Methanol & Water \\
\hline \multirow{3}{*}{ Alkaloids } & a). Mayer's reagent & - & + & - & - & - & + & + & - \\
\hline & b). Hager's reagent & - & + & + & + & - & + & + & - \\
\hline & c). Dragendorff's reagent & - & + & + & + & - & + & + & + \\
\hline \multirow{3}{*}{ Flavonoids } & a). Alkaline reagent & - & + & - & - & - & + & - & - \\
\hline & b). Lead acetate test & - & + & - & - & - & + & + & - \\
\hline & c). Ammonia test & - & + & - & - & - & + & - & - \\
\hline \multirow{3}{*}{ Phenols } & a). Alkaline reagent & - & + & + & + & - & - & + & + \\
\hline & b). Lead acetate test & - & + & - & + & - & + & + & + \\
\hline & c). Ferric chloride & - & + & + & + & - & - & + & + \\
\hline \multirow{4}{*}{ Tannins } & a). Iron salts test & - & - & + & + & - & - & + & + \\
\hline & b). Lead acetate test & - & + & - & + & - & + & + & + \\
\hline & c). Ferric chloride & - & + & + & + & - & - & + & + \\
\hline & d). $1 \%$ gelatin test & - & + & - & - & - & + & - & - \\
\hline \multirow{2}{*}{ Saponins } & a). Foam & - & - & - & + & - & - & - & + \\
\hline & b). $10 \% \mathrm{NaNO} 3$ test & - & + & - & + & - & + & - & + \\
\hline \multirow{2}{*}{ Steroid } & a). Salkowski's test & - & - & - & - & - & - & - & - \\
\hline & b). $3 \%$ Vanillin conc. $\mathrm{H}_{2} \mathrm{SO}_{4}$ & - & - & + & - & - & + & - & + \\
\hline \multirow{2}{*}{ Glycosides } & a). Liebermann's test & - & - & - & - & - & - & - & - \\
\hline & b). Salkowski's test & - & + & - & - & - & + & - & - \\
\hline \multirow{2}{*}{$\begin{array}{l}\text { Anthraquinones } \\
\text { glycosides }\end{array}$} & a). Borntrager's test & - & - & - & - & - & - & - & - \\
\hline & b).Modified Borntrager's & - & - & - & - & - & - & - & - \\
\hline Cardiac & a).Liebermann Bruchard's reagent & - & - & - & - & - & - & - & - \\
\hline glycosides & b). Keller- Kiliani reaction & - & - & - & - & - & - & - & - \\
\hline Terpenoids & Chloroform plus sulphuric acid & - & - & - & - & - & - & - & - \\
\hline
\end{tabular}

Table 1. Continued.

\begin{tabular}{|c|c|c|c|c|c|c|c|c|c|}
\hline \multirow{3}{*}{$\begin{array}{l}\text { Phytochemical } \\
\text { test }\end{array}$} & \multirow{3}{*}{ Reagents } & \multicolumn{8}{|c|}{ Results of Different Crinum species extract by different solvent } \\
\hline & & \multicolumn{4}{|c|}{ Crinum macowanii } & \multicolumn{4}{|c|}{ Crinum ornatum } \\
\hline & & n-Hexane & Ethanol & Methanol & Water & n-Hexane & Ethanol & Methanol & Water \\
\hline \multirow{3}{*}{ Alkaloids } & a). Mayer's reagent & - & + & + & - & - & + & + & - \\
\hline & b). Hager's reagent & - & + & + & + & - & + & + & - \\
\hline & c). Dragendorff's reagent & - & + & + & + & - & + & - & + \\
\hline \multirow{3}{*}{ Flavonoids } & a). Alkaline reagent & - & + & + & - & - & + & + & + \\
\hline & b). Lead acetate test & - & + & + & - & - & + & - & - \\
\hline & c). Ammonia test & - & + & + & - & - & + & + & + \\
\hline \multirow{3}{*}{ Phenols } & a). Alkaline reagent & - & - & + & - & - & + & + & - \\
\hline & b). Lead acetate test & - & + & + & - & - & - & + & + \\
\hline & c). Ferric chloride & - & + & + & + & - & + & + & - \\
\hline \multirow{4}{*}{ Tannins } & a). Iron salts test & - & - & - & + & - & - & + & - \\
\hline & b). Lead acetate test & - & + & + & - & - & - & + & + \\
\hline & c). Ferric chloride & - & + & + & + & - & + & + & - \\
\hline & d). $1 \%$ gelatin test & - & + & + & - & - & - & + & - \\
\hline \multirow{2}{*}{ Saponins } & a). Foam & - & - & - & + & - & - & - & - \\
\hline & b). $10 \% \mathrm{NaNO} 3$ test & - & - & - & - & - & - & - & - \\
\hline \multirow{2}{*}{ Steroid } & a). Salkowski's test & - & - & - & - & - & - & - & - \\
\hline & b). $3 \%$ Vanillin conc. $\mathrm{H} 2 \mathrm{SO} 4$ & - & - & - & - & - & - & - & - \\
\hline \multirow{2}{*}{ Glycosides } & a). Liebermann's test & - & - & - & - & - & - & - & - \\
\hline & b). Salkowski's test & - & + & - & - & - & - & - & - \\
\hline \multirow{2}{*}{$\begin{array}{l}\text { Anthraquinones } \\
\text { glycosides }\end{array}$} & a). Borntrager's test & - & - & - & - & - & - & - & - \\
\hline & b).Modified Borntrager's & - & - & - & - & - & - & - & - \\
\hline \multirow{2}{*}{$\begin{array}{l}\text { Cardiac } \\
\text { glycosides }\end{array}$} & a).Liebermann Bruchard's reagent & - & - & - & - & - & - & - & - \\
\hline & b). Keller- Kiliani reaction & - & - & - & - & - & - & - & - \\
\hline Terpenoids & Chloroform plus sulphuric acid & - & - & - & - & - & - & - & - \\
\hline
\end{tabular}

Note: The (+) represents presence, while (-) represents absence of a given phytochemical constituent.

Besides the findings presented in the Table 1, the positive tests results of phytochemical constituents were presented in the Figure 1.

\subsection{Quantitative Phytochemical Analysis}

The concentration of total alkaloids, flavonoids, saponins, 
phenols and tannins in the bulbs of Crinum species were presented in the Figure 2. It revealed that, the percentage concentration of flavonoids were higher in all Crinum species as compared with others phytochemical constituents. Similarly, the percentage concentrations of saponins were higher next to flavonoids in all species except Crinum ornatum. Moreover, the percentage concentration of alkaloids and phenols ranges from nearly $4 \%$ to $10 \%$ in all Crinum species. But, the percentage concentrations of tannins were smaller for all species.

\section{Percentage of Phytochemical Constituents}

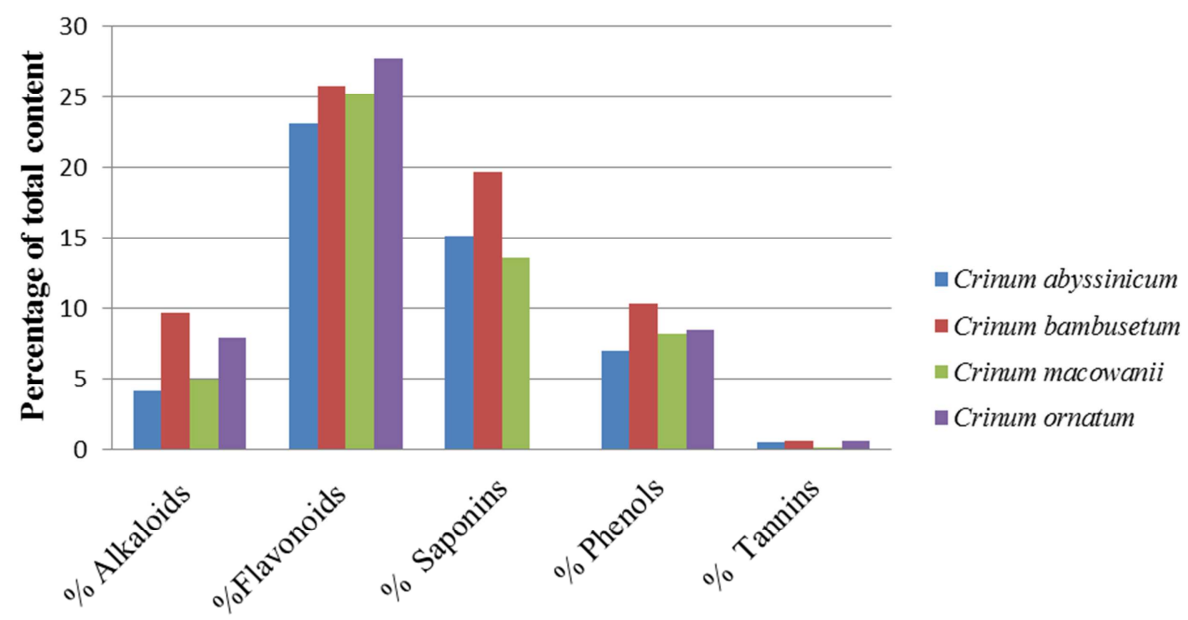

Phytochemical constituents

Figure 2. Percentage of the different phytochemical constituents in the bulbs of the four Crinum species.

As it can be depicted in the Table 2, the highest percentage of alkaloids content was found in Crinum bambusetum, followed by Crinum ornatum. The smallest percentage of alkaloids was found in Crinum macowanii and Crinum abyssinicum. In addition to this it revealed a statistically significant mean difference of the content of alkaloids between all Crinum species. Similarly, it found statistically significant mean difference of the content of flavonoids in all Crinum species except Crinum bambusetum and Crinum macowanii. Moreover, there was statistically significant mean difference of contents of saponins in all Crinum species except Crinum ornatum. And also, the mean difference of the content of phenols was found statistically significant across all Crinum species whereas no difference was found between Crinum macowanii and Crinum ornatum. Furthermore, less content of tannins with statistically significant average difference was found among Crinum species but, indifference was found between Crinum bambusetum and Crinum ornatum. From over all finding of chemical constituents, all Crinum species have low percentage of total contents of tannins than the other chemical constituents. The total phenol content of Crinum ornatum was determined to be much smaller $(84.7 \mathrm{mg} / \mathrm{g})$ than the amounts reported $(271.5 \mathrm{mg} / \mathrm{g})$ by literature [30]. The quantities of total flavonoids are also less $(27.72 \pm 0.22 \%)$ in amount than reported, $52.4 \pm 0.02 \%$ by the literature [35]. In other hand, leaves of Crinum latifolium exposed the presence of glycosides, alkaloids, tannins, phenols and the total phenol contents of methanol extract was $17.50 \pm 2.64 \mathrm{mg}$ of GAE/ gm of extract [36].

Table 2. Proportion of phytochemical constituents extracted from bulbs Crinum species.

\begin{tabular}{llllll}
\hline \multirow{2}{*}{ No } & \multirow{2}{*}{ Phytochemical } & Species & & & \\
\cline { 3 - 6 } & & C. abyssinicum [mean \pm SE] & C. bambusetum [mean \pm SE] & C. macowanii [mean \pm SE] & C. ornatum [mean \pm SE] \\
\hline 1 & Alkaloids & $4.09 \pm 0.07^{\mathrm{a}}$ & $9.66 \pm 0.02^{\mathrm{b}}$ & $4.99 \pm 0.04^{\mathrm{c}}$ & $7.92 \pm 0.07^{\mathrm{d}}$ \\
2 & Flavonoids & $23.13 \pm 0.15^{\mathrm{a}}$ & $25.78 \pm 0.12^{\mathrm{b}}$ & $25.22 \pm 0.2^{\mathrm{b}}$ & $27.72 \pm 0.22^{\mathrm{c}}$ \\
3 & Saponins & $15.18 \pm 0.43^{\mathrm{a}}$ & $19.72 \pm 0.18^{\mathrm{b}}$ & $13.57 \pm 0.41^{\mathrm{c}}$ & - \\
4 & Phenols & $6.98 \pm 0.1^{\mathrm{a}}$ & $10.33 \pm 0.32^{\mathrm{b}}$ & $8.23 \pm 0.2^{\mathrm{c}}$ & $8.47 \pm 0.01^{\mathrm{c}}$ \\
5 & Tannins & $0.47 \pm 0.02^{\mathrm{a}}$ & $0.61 \pm 0.03^{\mathrm{b}}$ & $0.13 \pm 0.00^{\mathrm{c}}$ & $0.55 \pm 0.00^{\mathrm{b}}$ \\
\hline
\end{tabular}

All values are expressed as mean \pm standard error (SE). Means indicated by the same lettered superscripts represent are not significant difference, Values were found out by using one-way analysis of variance (ANOVA) followed by Tukey test. Significance level $\mathrm{P}=0.05$.

\section{Conclusions}

This research work is initiated to detect the presence of bioactive compounds in the crinum species to study their importance for medicinal aspect. Due to the reason that, the concentration of phytochemicals varies accordingly, different solvents extract of the plant were selected for the analysis of phytochemicals compositions. The phytochemical screening of Crinum species showed that the bulbs were rich in phytochemical constituents. As results, the current study revealed the positive test for alkaloids, flavonoids, phenols, saponins and tannins in the crude extracts of with some 
reagents in all Crinum species except n-hexane solvent. On contrary, the Anthraquinones glycosides, cardiac glycosides and terpenoids for all crinum species were detected negative with all reagent tests in all solvent extracts. The presence of phytochemical constituents in bulbs of Crinum species extracts supports their traditional uses, pharmacological agents and modern drug discovery. Therefore, all Crinums species are useful for Antitumor, anti-coughs and colds, antiallergic, anti-inflammatory, antimicrobial, anticancer, antifungal activities and so on. In particular, the endemic Crinums species were rich of alkaloids, flavonoids, phenols, saponins and tannins.

\section{Authors' Contributions} Asnakech investigated all laboratory experiments and written the paper Participated on sample collection,

Tesfaye (Phd) sample identification, supervised the experiments and edited the paper

Abdella (Phd) Edited the paper

\section{Competing Interests}

The authors declare that they have no competing interests.

\section{Funding}

Not applicable.

\section{Acknowledgements}

Author would like to acknowledge Ethiopian Biodiversity Institute, Ethiopian Public Health Institute and National Soil Testing Center for their good willing me to use their laboratory space and facilities. Again special thanks goes to Mr. Ashenafi Senbeta and all others who directly or indirectly contributed to the success of this work.

\section{References}

[1] Sofowora A. Medicinal Plants and Traditional Medicine in Africa, 2nd Edition, Spectrum Books Limited (Publisher), Ibadan, Nigeria. 1993; 134-156.

[2] Oloyede G, Oladosu I, Shodia A. Chemical composition and cytotoxicity of the essential oils of Crinum ornatum (Ait.) Bury. Afr. J. Pure and Appl. Chem. 2010; 4: 35-37.

[3] Akintola A, Kehinde A, Adebiyi O, Ademowo O. Antituberculosis activities of the crude methanolic extract and purified fractions of the bulb of Crinum jagus. Nigerian J. Physiolog. Sci. 2014; 28: 135-140.

[4] Lawal A, Dangoggo S. Phytochemical, Proximate and Toxicity Studies of Aqueous Extract of Crinum ornatum (Toad's Onion). Chem. Search Journal. 2014; 5: 45-50.

[5] Nordal Inger and Sebsebe Demissew. Aloes and Lilies of
Ethiopia and Eritrea January. 2010; 162-163.

[6] Adesanya SA, Olugbade TA, Odebiyi OO, Aladesanmi JA. Antibactwrial Alkaloids in Crinum jagus. International $\mathrm{J}$. Pharmacognosy. 1992; 4: 303-307.

[7] Reta Regassa. Assessment of indigenous knowledge of medicinal plant practice and mode of service delivery in Hawassa city, southern Ethiopia. 2013; 531.

[8] Firaol Tamiru, Waktole Terfa, Ejigu Kebede, Gizaw Dabessa, Rajeeb KR, Mekonnen Sorsa. Ethno-knowledge of plants used in veterinary practices in Dabo Hana District, West Ethiopia. Journal of Medicinal Plant Research. 2013; 7 (40): 2960-2971.

[9] Haile Yinger, Ensermu Kelbessa, Tamrat Bekele, Ermias Lulekal. Plants used in traditional management of human ailments at Bale Mountains National Park, Southeastern Ethiopia. Journal of Medicinal Plants Research. 2008; 2 (6): 132-153

[10] Hasler CM, Blumberg JB. Symposium on Phytochemicals: Biochemistry and Physiology. Journal of Nutrition. 1999; 129: $756 \mathrm{~S}-757 \mathrm{~S}$

[11] Refaat J., Kamel M. S., Ramadan M. A. and Ali A. A (2013).Crinum; An Endless Source of Bioactive Principles: A Review. Part V. Biological Profile. IJPSR. 2013; 4 (4): 1239-1252.

[12] Parekh J, Chanda, S. In Vitro Antibacterial Activity Of Crude Methanol Extract Of Woodfordia Fruticosa Kurz Flower (Lythacease). Brazilian Journal of Microbiology. 2007; 38: 2-3.

[13] Parekh J, Nair R, Chanda S. Preliminary screening of some folkloric plants from western India for potential antimicrobial activity. Indian J Pharmacol. 2005.

[14] Harborne JB. Phytochemical methods. A guide to modern techniques of plant analysis. Chapman and Hall, London. 1998; 5- 37

[15] Harborne JB. Phytochemical methods. A guide to modern techniques of plant analysis. Chapman and Hall, London. 1973; 279: 49-188.

[16] Ciulci I. Methodology for the Analysis of Vegetable Drugs. ChemicalIndustries Branch, Division of Industrial Operations. Unido, Romania. 1994; 24: 26-67.

[17] Raman N. Phytochemical Methods, New Indian Publishing Agencies, New Delhi. 2006; 19.

[18] Menghani E, Bhatnagar K, Saraswat P, Soni M. Isolation and characterization of bioactives from arid zone plants. International journal of pharmaceutical research and development. 2011; 4 (2): 113-118.

[19] Misra, CS, Pratyush K, Dev MSL, James J, Veettil AKT, et al. A comparative study on phytochemical screening and antibacterial activity of roots of Alstoniascholaris with the roots, leaves and stem bark. International journal of resource phytochemistry and pharmacology. 2011; 1 (2): 77-82.

[20] Obadoni BO, Ochuko PO. Phytochemical studies and comparative efficacy of the crude extracts of some homeostatic plants in Edo and Delta States of Nigeria. Global J. Pure Appl. Sci. 2001; 8: 203-208.

[21] Boham BA, Kocipal-Abyazan R. Flavonoids and condensed tannins from leaves of Haiwaiian Vaccinium vaticulatum and V.calycinium. Pacific Sci. 1974; 48: 458-463. 
[22] Okwu DE, Josiah C. Evaluation of the chemical composition of two Nigerian Medical plants. Afr. J. Biotechnol. 2006; 5 (4): $357-361$

[23] Singleton VL, Orthofer R, Lamuela-Raventos RM. Analysis of total phenols and other oxidation substrates and antioxidants by means of Folin-Ciocalteu reagent. Methods Enzymol. 1999; 299: 152-178.

[24] Marinova D, Ribarov F, Atanassova M. Total Phenolics and Total Flavonoids in Bulgarian Fruits and Vegetables. J University Chem Technol Metallurgy. 2005; 40 (3): 255-260.

[25] Rajeev Singh, Pawan Kumar Verma, Gagandeep Singh. Total phenolic, flavonoids and tannin contents in different extracts of Artemisia absinthium. J Intercult Ethnopharmacol. 2012; 1 (2): 101-104.

[26] AfifyAel M, El-Beltagi HS, El-Salam SM, Omran AA. Biochemical changes in phenols, flavonoids, tannins, vitamin $\mathrm{E}, \beta$-carotene and antioxidant activity during soaking of three white sorghum varieties. Asian Pac J Trop Biomed. 2012; 2 (3): 203-9.

[27] Nair JJ, Machocho AK, Campbell WE, Brun R, Viladomat F, et al. Alkaloids from Crinum macowanii. Phytochemistry. 2000; 54 (8): 945-950.

[28] Mugabo P, Obikeze KC, Njagi A, Burger PA, Green I, et al. Cardiovascular Effects of the Alkaloid Hippadine On the isolated perfused rat heart. 2012; 2 (1): 172 -177.

[29] Kouam, MF, Flavien AAT, Jean DW, Alain FKW, Neil AK, et al. 2014.
[30] Mohammed ZK, Modu, SAD, Olukade MF, Fatimah SS, Falmata AS, etal. Acute Toxicity Study on the Bulb of Crinum ornatum (Ait Bury).Bull. Env. Pharmacol. Life Sci. 2014; 3 (9): 168-171.

[31] Ganiyat KO, Yunus R. Preliminary Anticonvulsant Screening of Crinum Ornatum Bulbs extract, African Journal of Basic \& Applied Sciences. 2011; 3 (5): 235-238.

[32] Tram NT, Titorenkova T, Bankova V, Handjieva N, Popov SS. Crinum L. Amaryllidaceae. Fitoterapia. 2002; 73 (3): 183-208.

[33] Mvongo C, Noubissi PA, Kamgang R, Minka CS, Mfopa A, et al. Phytochemical Studies and In Vitro Antioxidant Potential of Two Different Extracts of Crinum Jagus. Int J Pharm Sci Res. 2015; 6 (6): 2354-59. doi: 10. 13040/IJPSR.0975-8232.

[34] Shilpa. K, Rajendra Y, Sanjeeva KA, Vinay KD, Vinod KR, et al. Evaluation of Wound Healing Potential in Crinium defixum Ker Gawl Bulbs, Asian J Pharm Clin Res. 2013; 6 (1): 61-63.

[35] Abubakar LL, Guan HT, Mohammed AA. Edibility and Medicinal Studies of Crinum ornatum in Comparison with Allium Sativum Pak. J. Nutr. 2015; 14 (11): 773-781.

[36] Aziz A, Golam SR, Abhijit D, Jamiuddin A, Mizanur RM. Evaluation of In vitro Anthelmintic Activity, Total Phenolic Content and Cytotoxic Activity of Crinum latifolium L. (Family: Amaryllidaceae), Advanced Pharmaceutical Bulletin. 2014; 4 (1): 15-19. 